\title{
Going Green Through Green Supply Chain Initiatives Towards Environmental Sustainability
}

\author{
Tarig Khidir Eltayeb \\ School of Management, Universiti Sains Malaysia \\ 11800 Penang, Malaysia \\ Suhaiza Zailani * \\ School of Management, Universiti Sains Malaysia \\ 11800 Penang, Malaysia \\ shmz@usm.my
}

\begin{abstract}
In recent years the natural environment becomes a major global issue. Due to increasing human and industrial impacts on the environment, environmental issues become more intense and widespread. In this regard, businesses need to place equal footing both on the environment and on their business objectives. This paper is an attempt to clarify the path towards that end and highlight steps to be taken by business organizations through green supply chain to make sustainable development a reality. Specifically the paper is interested to investigate the adoption of green supply chain initiatives. Three green supply chain initiatives e.g. green purchasing, eco-design, and reverse logistics were studied. The survey data was obtained from ISO 14001 certified manufacturing firms in Malaysia. The survey was conducted using structured mail questionnaire directed to the environmental management representative (EMR) in each firm. The results showed that ecodesign is the most adopted green supply chain initiative followed by green purchasing, while reverse logistics showed the lowest level of adoption. The result of the $t$-test revealed that there are no significant differences in green supply chain initiatives between firm ages and type of product. However, firms with large supplier base (more than 10 suppliers) are found to be significantly higher in green purchasing and eco-design than firms with lower supplier base. The result of the t-test disclosed also that firms that participate in greeninterested associations have significantly higher level of adoptions of green supply chain initiatives than firms that do not participate. Green supply chain initiatives can play significant role in achieving the "triple bottom line" of social, environmental, and economic benefits and, therefore, contributing to sustainable development of the society.
\end{abstract}

Keywords: green supply chain initiatives, adoptions, environmental sustainability, Malaysian certified companies

\section{Introduction}

In recent years the natural environment becomes a major global issue. Due to increasing human and industrial impacts on the environment, environmental issues become more intense and widespread. Global warming and ozone depletion have emerged as major pollution issues (IPCC, 2007). Species diversity and degradation of natural resources is becoming the subject of international debate. Today, environmental issues have been increasingly integrated into international trade, and

*Corresponding Author 
markets and consumers worldwide are increasingly demanding environmentally friendly products (Anbumozhi \& Kanda, 2005).

Environmental problems today have expanded from local and regional ones, to global ones (Banerjee, 2001). It is a well-known fact that the global environmental carrying capacity reached its limit. Natural resources including mineral ores and fossil fuels, agricultural productivity, and the selfpurification capacity of the natural environment all have their own limits (WBCSD, 2006). Irrational resource consumption together with irresponsible environmental pollution resulting from the entire product life cycle-raw material acquisition, manufacturing, use and disposal-are the main reasons this global environmental carrying capacity is being exceeded (Matos \& Hall, 2007). These realities require immediate action by business organizations, governments, and society to achieve a balanced growth that tries to achieve economic and social objectives without scarifying the environment. In this regard, businesses need to place equal footing both on the environment and on their business objectives. This calls for considering the issues of sustainable development in business operations. Sustainable development is defined as "meeting the needs of the present generation without compromising the ability of future generations to meet their own needs" (WCED, 1987). Therefore, business activities need to be evaluated on the basis of impact of these activities on natural environment. In addition to alleviating negative effect on the environment, integration of environmental aspects into business operations can generate significant economic benefits to business organizations. There is increasing evidence that environmental improvement is good business (Porter \& van der Linde, 1995).

Malaysia is moving forward to be an industrialized economy. Malaysia moved from material production to manufacturing. The Malaysian manufacturing sector contributed $32 \%$ of the gross domestic product (GDP) in 2007, exports of manufactured products account for $75 \%$ of Malaysia's total export in 2007 (MIDA, 2007). The manufacturing industries have become the economy's main source of growth in recent years. However, such rapid industrialization has detrimental effect on the environment due to the increase in the pollution, waste, and rapid consumption of natural resources.
Industry or individual corporations are the single most important source of environmental problems. This is because human society depends heavily on industrial products to sustain its living standard. Corporations consume resources and emit environmental emissions because of the products they manufacture. These are, however, not significant quantities compared to what a product generates during its life cycle. A typical example would include durable goods such as home appliances and automobiles. Environmental loads from the use and disposal stages are much greater than that from the manufacturing stage. For goods like paper towels and aluminum foil, environmental loads from the manufacturing stage are relatively high; however, the total load is still greater than that from the manufacturing stage. Therefore, environmental loads occurring throughout a product life cycle are the main cause of today's environmental problem (Abdullah, 1995).

Despite existing efforts to alleviate environmental problems, environmental problems have not been mitigated; rather, they tend to have been aggravated (MGCC, 2006). In recent years, more effective approaches for environmental management have been proposed. These approaches shifted environmental management (EM) from just the end-of-pipe control and treatment of waste (Handfield et al., 2005; Sinding, 2000). Firms should accept responsibility for environmental impacts which were once regarded as incidental externalities. Thus, they have to move from an environmental management paradigm that focuses on clean up and control to one that embraces avoidance of environmental harm through entire product life cycle (Handfield et al., 2005). Treading this path requires more comprehensive means to reduce pollution through attacking the source of pollution at every stage of the product life cycle that include raw material extraction, transportation, manufacturing, product use, recycling, and disposal (Matos \& Hall, 2007) Specific, corporate environmental strategies range from simple environmental impact assessment (EIA) and waste minimization to more sophisticated eco-efficiency and green supply chain as follows to pollution prevention and ultimately total product stewardship or green supply chain as shown in Figure 1 below. 
Figure1. The Shift in Environmental Management

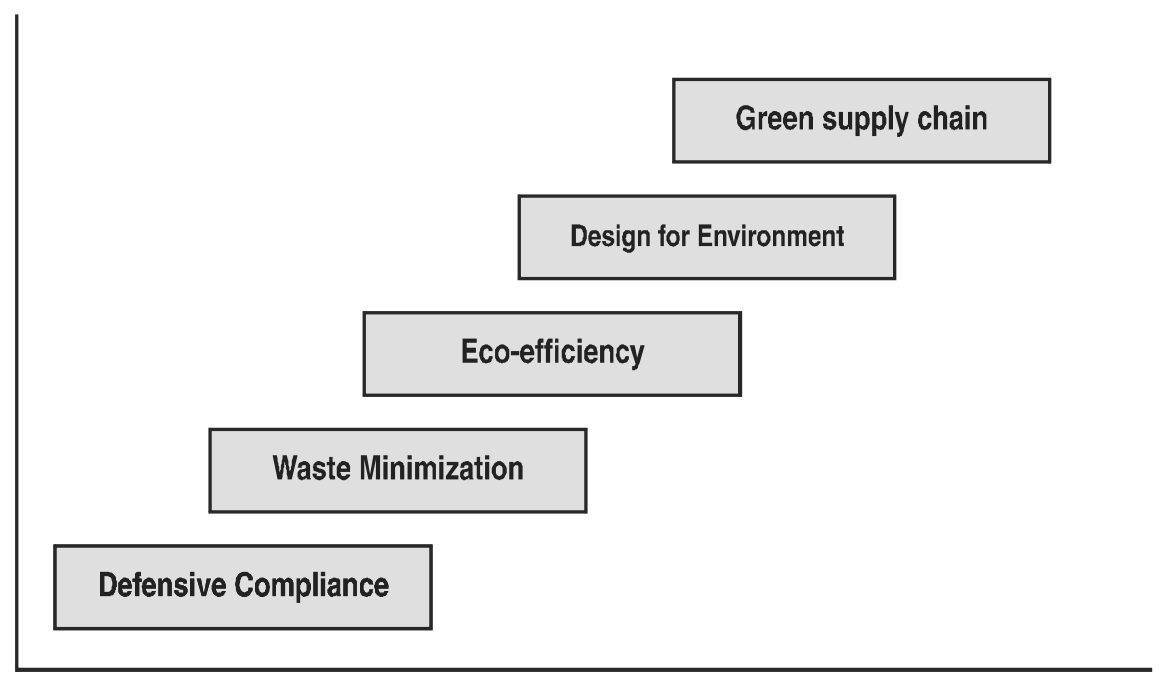

The steps taken by business organizations towards sustainability can be summarized as follows:

1. Defensive compliance: Firms can be reactive in environmental management and simply comply with existing regulations. Environmental issues are generally seen as a regulatory nuisance to be met only because noncompliance would result in severe financial penalties (Handfield et al., 1997).

2. Waste minimization or cleaner production: There are two central waste strategies that companies can adopt in their pursuit of waste minimization (Sinding 2000).

3. Eco-efficiency: World Business Council for Sustainable Development (WBCSD, 2006) define eco-efficiency in terms of delivery of competitively priced goods and services designed to satisfy human need and enhance quality of life, while progressively reducing environmental impacts and resource intensity throughout the life cycle to a level at least in line with the earth's estimated carrying capacity.

4. Design for environment: DFE incorporates considerations of material's recyclability and reusability, the materials' long term impact on the environment, the amount of energy required for the product's manufacture and use, the capability for easy disassembly for remanufacturing, and considerations of the product's durability and disposal characteristics (Sarkis, 1998).

5. Green supply chain: Green supply chain involves evaluating total environmental effects of products through its entire life cycle of products and services (Handfield et al., 2005). Extending green activities throughout the supply chain represents an evolution over environmental assessments focused on firm-specific impacts and endof-pipe analysis, and is now part of many organizations' broader sustainable efforts (Matos \& Hall, 2007).

With regards to green supply chain, it is necessary for the study to investigate the level of adoptions of green initiatives among certified companies in Malaysia. Therefore, the paper is organized as follows. Next section will discuss on the literature especially on the green supply chain initiatives; e.g. eco system, green purchasing and reverse logistic. This is followed by the methodology. The following section is on the analysis. Discussions, implications, recommendations and conclusions sections end the paper. 


\section{Literature Review}

\subsection{Green Supply Chain Initiatives}

The concept of green supply chain is a multidisciplinary issue that emerges mainly from performing environmental management practices in the context of supply chains (Sarkis, 2006; Walton, Handfield \& Melnyk, 1998). Environmental management represents specification of how organizations care about the natural environment and minimize the negative environmental effects of their entire operations (Klassen \& McLaughlin, 1996; Welford, 2000). Environmental management principles specify policies, procedures, and audit protocols for controlling operations that create waste materials or emissions (Matthews, 2003). These principles usually take the form of standardized EMS such as British Standard for EMS BS7750 (1994), the EU eco-management and audit scheme (1993), and the international standard ISO 14000 (Bansal \& Clelland, 2004). These standards have been developed to provide organizations with a framework to implement EMS (Netherwood, 1996).
While environmental management principles and standards provide powerful tools that have a potential to generate significant improvements to environmental performance of organizations, their focus restricted only on creating and documenting environmental policies and procedures (Curkovic et al., 2005). Such policies and procedures may represent efforts to improve environmental performance only within the organization's operational boundaries rather than being extended throughout the supply chain (Bansal \& Clelland, 2004; Handfield, et al., 2005). Firms can market themselves as being environmentally proactive (by virtue of having an EMS) without undertaking the effort of "greening" their supply chains (Darnall, Jolley \& Handfield, 2006). Unlike the traditional environmental management, the concept of green supply chain assumes full responsibility of a firm towards its products from the extraction or acquisition of raw materials up to final use and disposal of products (Hart, 1997). It represents application of environmental management principles to the whole set of activities spanning the entire customer order cycle, including design, procurement, manufacturing

Table 1. Green Supply Chain Initiatives Based on Literature

\begin{tabular}{|l|l|}
\hline \multicolumn{1}{|c|}{ Source } & \multicolumn{1}{c|}{ Green Supply Chain Initiatives } \\
\hline Alvarez-Gil, Berrone, Husillos and Lado (2007) & Reverse logistics \\
Vachon and Klassen (2007) & Customer and supplier environmental collaboration \\
Zhu, Sarkis \& Lai (2007) & Green purchasing, eco-design, customer cooperation. \\
Rao (2006) & Green purchasing \\
Vachon and Klassen (2006) & Environmental collaboration with suppliers and customers. \\
Hervani, Helms and Sarkis (2005) & Green design, green procurement, green distribution, and reverse logistics. \\
Ravi et al. (2005) & Reverse logistics. \\
Richey, Genchev and Daugherty (2005) & Reverse logistics. \\
Murphy and Poist (2003) & Green logistics \\
Rao (2002) & Green purchasing, supplier environmental collaboration. \\
Bowen et al. (2001a,b) & Green purchasing, supplier environmental collaboration. \\
Canning and Hanmer-Lloyd (2001) & Environmental adaptations to supplier-customer relationships. \\
Min and Galle (2001) & Green purchasing \\
Preuss (2001) & Green purchasing \\
Hall (2000) & Diffusion of environmental innovations from customers to suppliers \\
Beamon (1999) & Eco-design, Reverse logistics. \\
Blumberg (1999) & Reverse logistics \\
Carter and Carter (1998) & Green purchasing. \\
Carter and Ellram (1998) & Reverse logistics \\
Sarkis (1998) & Design for the environment, life cycle analysis, and reverse logistics. \\
Walton et al. (1998) & Design for the environment, green purchasing. \\
& \\
\hline
\end{tabular}


and assembly, packaging, logistics, and distribution (Handfield et al 1997; Zsidisin \& Siferd, 2001). This implies that there is a wide range of initiatives that can be performed within green supply chains. As a result, there is a disagreement among scholars regarding what green supply chain initiatives are. Table 1 presents some of green supply chain initiatives that have been widely discussed in the literature.

Table 1 indicates that green supply chain initiatives can be generally classified into the following categories:

(1) Eco-design or design for the environment

(2) Green purchasing

(3) Reverse logistics

\subsubsection{Eco-Design}

Eco-design (environmental-conscious design), also called design for the environment and green design, refers to actions taken during product development aim at minimizing a product's environmental impact during its whole life cycle - from acquiring materials, to manufacturing, use, and ultimately to its final disposal - without compromising other essential product criteria such as performance and cost (Johansson, 2002). Accordingly, eco-design is considered one of the green supply chain initiatives because it integrates environmental aspects into product design process, taking into consideration entire flow of the product in its supply chain. This consideration is very important because the majority of environmental impacts arising from production, consumption and disposal of the product are direct consequences of decisions made at the design stage (Handfield, Melnyk, Calantone, \& Curkovic, 2001). At the design stage, the function of the product, process or service is defined, and raw materials, supplies and process chemicals are selected. These in turn determine the energy which will be consumed to create them and the waste which will be generated. In addition, the durability, serviceability and energy consumption of products during their lifetime will also be determined (World Business Council for Sustainable Development (WBCSD), 2007). The specific eco-design actions or activities vary between companies and products. However, the basic eco-design activites include the following:
1. Design for reduction or elimination of environmentally-hazardous materials such as lead, mercury, chromium and cadmium (Zsidisin \& Siferd, 2001).

2. Design for reuse, is a design that facilitates reuse of a product or part of it with no or minimal treatment of the used product (Sarkis, 1998).

3. Design for recycling, is a design that facilitates disassembly of the waste product, separation of parts according to material, and reprocessing of the material (Lin, Jones \& Hsieh, 2001).

4. Design for remanufacturing, is a design that facilitates repair, rework, and refurbishment activities aiming at returning the product to the new or better than new condition (Beamon, 1999).

5. Design for resource efficiency, including reduction of materials and energy consumption of a product during use, in addition to promoting the use of renewable resources and energy (APO, 2004).

\subsubsection{Green Purchasing}

Green purchasing is an environmentally-conscious purchasing initiative that tries to ensure that the purchased products or materials meets environmental objectives set by the purchasing firm, such as reducing sources of waste, promoting recycling, reuse, resource reduction, and substitution of materials (Carter, Ellram \& Ready, 1998; Min \& Galle, 2001; Zsidisin \& Siferd, 2001). Green purchasing means that purchasing or supply chain managers consider the issue of sustainability in their purchasing of inputs in addition to the traditional purchasing criteria of cost, quality, and delivery (Lambert \& Cooper, 2000). Several green purchasing activities can be identified from the literature. Hamner (2006) summarized the basic green purchasing activities in seven points as follows:

1. Product content requirements: buyers specify that purchased products must have desirable green attributes such as recycled or reusable items.

2. Product content restrictions: buyers specify that purchased products must not contain 
environmentally undesirable attributes such as lead, CFCs, plastic foam in packaging materials.

3. Product content labeling or disclosure: buyers require disclosure of the environmental or safety attributes of purchased product content. Such disclosure can be done using green seals and indicators of relative environmental impact such as scientific certification system offered by various commercial organizations.

4. Supplier questionnaires: buyers send questionnaires to suppliers asking them to provide information about their environmental aspects, activities and/or management systems.

5. Supplier environmental management systems: buyers require suppliers to develop and maintain an environmental management system (EMS). However the buyer does not require supplier to certify the system.

6. Supplier certification: buyers require suppliers to have an EMS that is certified as fully compliant with one of the recognized international standards such as the British Standard 7750 (BS 7750), ISO 14001 from the International Organization for Standardization (ISO), and the European Union EcoManagement and Audit Scheme (EMAS).

7. Supplier compliance auditing: buyers audit suppliers to determine their level of compliance with environmental requirements.

\subsubsection{Reverse Logistics}

Reverse logistics focuses primarily on the return or take-back products and materials from the point of consumption to the forward supply chain for the purpose of recycling, reuse, remanufacture, repair, refurbishing, or safe disposal of the products and materials (Carter \& Ellram, 1998; Stock 1998). Reverse logistics encompasses the traditional logistics activities of transportation and inventory management, but its focus is to get product back from customers rather than moving product to customers (Goldsby \& Stank, 2000; Mollenkopf \& Closs, 2005). Used or end-of-life products returned into the forward supply chain for three main purposes (Beamon, 1999; Wells \& Seitz, 2005):
1. Reuse, is the process of collecting used products from the field, and distributing or selling them used. Thus, although the ultimate value of the product is reduced from its original value, no additional processing is required.

2. Remanufacturing, is the process of collecting a used product or component from the field, assessing its condition, and replacing worn, broken, or obsolete parts with new or refurbished parts. In this case, the identity and functionality of the original product is retained.

3. Recycling, is the process of collecting used products, disassembling them (when necessary), separating them into categories of like materials (e.g. specific plastic types, glass, etc.), and processing them into recycled products, components, and/or materials. In this case, the identity and functionality of the original materials is lost.

\section{Research Methodology}

This study conducted a survey to obtain quantitative data for statistical testing of the hypotheses. The survey was conducted using mail questionnaire. Mail questionnaire method was employed in this study because of its advantage of covering wide geographical area with less time and cost (Sekaran, 2003). The unit of analysis of the study is the individual firm. The population of this study consists of all EMS ISO 14001 certified manufacturing firms in Malaysia. The term "firm" here refers to companies as well as individual units or sites within companies. ISO 14001 certified firms were selected because they are expected to be embarked in the adoption of green purchasing initiatives. This is supported by the studies of Darnall, Jolly and Handfield (2006), Sroufe, (2003), and Zhu, Sarkis, Cordeiro, and Lai (2008). A sampling frame is a list of all elements in a population (Sekaran, 2003). For this study, the sampling frame represents all ISO 14001 certified firms in Malaysia. The sampling frame was obtained from SIRIM organization in addition to the Federation of Malaysian Manufacturers (FMM) directory 2007 of Malaysian manufacturers (FMM 2007). These two sources provided a sampling frame 
of 569 certified manufacturing firms in Malaysia by 2007. Given the small sampling frame of the study and the likelihood of low response from mail survey (Sekaran, 2003); all the 569 are included in the study. Thus, the sampling technique employed in this study is census. As such, the study made a mail survey of a total of 569 ISO 14001 certified firms in Malaysia.

This study combines issues related to the environment (green issues) with business aspects (supply chain). Therefore, the appropriate person to get the required data from should ideally have knowledge about the two aspects. Certification organizations usually appoint an Environmental Management Representative (EMR) in each firm to act as a link between the certification organization and the certified firm. The EMR can belong to any department in the certified firm but mainly comes from operations, quality control, and environmental health and safety departments. The EMR keeps all the documents regarding green issues in his firm and makes regular updating to the certification organization about progress in environmental performance in his firm. Because this person is expected to be highly informative about green issues in his firm, in addition to his knowledge about the business issues, this person is considered to be the most appropriate respondent. Therefore, the questionnaires were addressed to the EMR in each firm.

\subsection{Measures}

To investigate the extent of green supply chain initiatives adoptions, the study developed measures of each variable based on previous studies and selfconstruct. In this study, green supply chain initiatives have three dimensions: eco-design, green purchasing, and reverse logistics. Following similar studies on green supply chain initiatives (e.g., Vachon and Klassen, 2006a, Zhu, Sarkis \& Lai, 2007), the study uses a 5-point Likert scale for all dimensions of green supply chain initiatives ranging from $1=$ not at all adopted to $5=$ very high extent of adoption. Operational definitions and measurement items for each dimension of green supply chain initiatives are illustrated below.

\subsubsection{Eco-Design}

Eco-design is defined in this study as an environmental-conscious design of a product and its packaging that aims at minimizing negative environmental impacts of the product and its packaging throughout its entire life and promoting positive environmental practices such as recycling and reusing of the product and its packaging (Johansson, 2002; Zhu, Sarkis \& Lai, 2007). Ecodesign encompasses consideration of certain elements during product design including reduction or elimination of hazardous items, reuse, recycling, remanufacturing, and resource efficiency (material and energy) during product use (APO, 2004; Sarkis, 1998). Since life cycle assessment (LCA) is integral part of eco-design (Sarkis, 1998; Zutshi \& Sohal, 2004), it is included in the measurement of ecodesign. Eco-design activities can be conducted for product itself and its packaging (Sarkis, 1998). Therefore, the measurement of eco-design needs to encompass green design items for both products and packaging. Accordingly, a measurement for ecodesign was developed that encompasses all the elements shown above. The measurement items are adapted from Sarkis (1998) and Zhu, Sarkis and Lai (2007) as shown in Table 2 below.

Table 2. Items for Eco-Design

\begin{tabular}{|c|l|l|}
\hline No. & \multicolumn{1}{|c|}{ Items: Currently my firmÖ } & \multicolumn{1}{|c|}{ Source } \\
\hline 1 & $\begin{array}{l}\text { Produces products that have reused or recycled } \\
\text { materials in their contents such as recycled } \\
\text { plastics and glass. } \\
2\end{array}$ & $\begin{array}{l}\text { Uses life cycle assessment to evaluate } \\
\text { the environmental load of its products. }\end{array}$ \\
3 & $\begin{array}{l}\text { Produces products that are free from hazardous } \\
\text { substances such as lead, mercury, chromium, }\end{array}$ & Sarkis (1998) \\
and cadmium. & Zhu, Sarkis and Lai \\
4 & $\begin{array}{l}\text { Makes sure that its products have recyclable or } \\
\text { reusable contents. }\end{array}$ & Zhu, Sarkis and Lai \\
5 & $\begin{array}{l}\text { Produces products that reduce the consumption } \\
\text { of materials or energy during use. }\end{array}$ & 2007) \\
6 & $\begin{array}{l}\text { Makes sure that its packaging has recyclable } \\
\text { Contents. }\end{array}$ & Sarkis and Lai \\
7 & $\begin{array}{l}\text { Makes sure that its packaging is reusable. } \\
8\end{array}$ & Minimizes the use of materials in its packaging. \\
9 & $\begin{array}{l}\text { Avoids or reduces the use of hazardous materials } \\
\text { in its packaging. }\end{array}$ & Sarkis (1998) \\
Sarkis (1998)
\end{tabular}




\subsubsection{Green Purchasing}

Green purchasing is defined as an environmentallyconscious purchasing practice that aims at ensuring that purchased items meets environmental objectives of the firm such as reducing or eliminating hazardous items, reducing sources of waste, and promoting recycling and reclamation of purchased materials (Carter, Ellram \& Ready, 1998; Min \& Galle, 2001; Zsidisin \& Siferd, 2001). The measurement for green purchasing is developed based on the seven basic elements of green purchasing suggested by Hamner (2006): product content requirements, product content restrictions, product content labeling or disclosure, supplier questionnaires, supplier EMSs, supplier certification, and supplier compliance auditing. The specific items that reflect these seven items are adapted from Carter, Ellram and Ready (1998) and Zhu, Sarkis and Lai (2007), in addition to Hamner (2006) as shown in Table 3 below.

Table 3. Items for Green Purchasing

\begin{tabular}{|c|c|c|}
\hline No. & Items: Currently my firmÖ & Source \\
\hline 1 & $\begin{array}{l}\text { Provides design specifications to suppliers that } \\
\text { include environmental requirements for } \\
\text { purchased items. }\end{array}$ & Zhu et al. (2007) \\
\hline 2 & $\begin{array}{l}\text { Requires its suppliers to develop and maintain } \\
\text { an environmental management system (EMS). }\end{array}$ & Zhu et al. (2007) \\
\hline 3 & $\begin{array}{l}\text { Requires its suppliers to have a certified EMS } \\
\text { such as ISO } 14001 .\end{array}$ & Zhu et al. (2007) \\
\hline 4 & $\begin{array}{l}\text { Uses a questionnaire to collect information about } \\
\text { its suppliers' environmental aspects, activities } \\
\text { and/or management systems. }\end{array}$ & Hamner (2006) \\
\hline 5 & $\begin{array}{l}\text { Makes sure that its purchased products must } \\
\text { contain green attributes such as recycled } \\
\text { or reusable items. }\end{array}$ & Hamner (2006) \\
\hline 6 & $\begin{array}{l}\text { Makes sure that its purchased products must } \\
\text { not contain environmentally undesirable items } \\
\text { such as lead or other hazardous or toxic materials }\end{array}$ & Carter et al. (1998) \\
\hline 7 & $\begin{array}{l}\text { Evaluates its suppliers based on specific } \\
\text { environmental criteria. }\end{array}$ & Hamner (2006) \\
\hline 8 & $\begin{array}{l}\text { Evaluates the environmental aspects of its } \\
\text { second-tier suppliers. }\end{array}$ & Zhu et al. (2007) \\
\hline 9 & $\begin{array}{l}\text { Makes sure that its suppliers meet its } \\
\text { environmental objectives. }\end{array}$ & Carter et al. (1998) \\
\hline
\end{tabular}

\subsubsection{Reverse Logistics}

Reverse logistics is defined as the return or take-back of a product or packaging, after use, from customers or to suppliers for the purpose of reuse, recycling, reclamation of materials from the product or packaging, or safe refill of products (Carter \& Ellram, 1998; Stock 1998). This definition illustrates that reverse logistics involves return activities from customers at products' end of life in addition to return of purchased items to suppliers for the purposes of recycling, reuse, or reclamation of materials. Moreover, the definition illustrates that reverse logistics can be performed for the product and its packaging (Rogers \& Tibben-Lembke, 2001). Therefore the measure for reverse logistics needs to encompass items that reflect both elements. Six items that reflect these concepts are adapted from Carter and Ellram (1998) and Rogers and Tibben-Lembke (2001) as shown in Table 4 below.

Table 4. Items for Reverse Logistics

\begin{tabular}{|c|c|c|}
\hline No. & Items: Currently my firmÖ & Source \\
\hline 1 & $\begin{array}{l}\text { Collects back used products from customers for } \\
\text { recycling, reclamation of materials, or reuse. }\end{array}$ & $\begin{array}{l}\text { Carter and Ellram } \\
\text { (1998) }\end{array}$ \\
\hline 2 & $\begin{array}{l}\text { Collects back used packaging from customers } \\
\text { for reuse or recycling. }\end{array}$ & $\begin{array}{l}\text { Rogers and Tibben- } \\
\text { Lembke (2001) }\end{array}$ \\
\hline 3 & $\begin{array}{l}\text { Requires suppliers to collect back their packaging } \\
\text { materials. }\end{array}$ & $\begin{array}{l}\text { Carter and Ellram } \\
(1998)\end{array}$ \\
\hline 4 & $\begin{array}{l}\text { Returns back its products to suppliers for } \\
\text { recycling, retaining of materials, or } \\
\text { remanufacturing. }\end{array}$ & $\begin{array}{l}\text { Rogers and Tibben- } \\
\text { Lembke (2001) }\end{array}$ \\
\hline 5 & $\begin{array}{l}\text { Returns back its packaging to suppliers for reuse } \\
\text { or recycling. }\end{array}$ & $\begin{array}{l}\text { Rogers and Tibben- } \\
\text { Lembke (2001) }\end{array}$ \\
\hline 6 & $\begin{array}{l}\text { Returns back the products from customers for } \\
\text { safe refill. }\end{array}$ & $\begin{array}{l}\text { Carter and Ellram } \\
(1998)\end{array}$ \\
\hline
\end{tabular}

\section{Analysis}

The total population of the study is 569 firms. Given that this study is using consensus, all the 569 firms are used in the study. However, after excluding the 16 firms used for the pre testing of the questionnaire and the two firms used for the interviews, the population of the study becomes 551. Accordingly, a total of 551 questionnaires were mailed to the

Table 5. Response Rate of the Survey

\begin{tabular}{|lr|}
\hline Total questionnaires sent to respondents & 551 \\
\hline Questionnaires returned from respondents & 138 \\
\hline Unusable questionnaires (partially completed) & 6 \\
\hline Usable completed questionnaires & 132 \\
\hline Overall response rate & $25 \%$ \\
\hline Usable response rate & $23.96 \%$ \\
\hline
\end{tabular}


respondents. After two reminder letters in addition to telephone calls and e-mails, 132 completed questionnaires were received. The response rate is $24 \%$. Table 5 presents summary for the response rate. This response rate is considered acceptable given the low response expected from mail survey (Sekaran, 2003) and generally low response rate for this type of correlational study in Malaysia. The response rate is also considered acceptable compared to other similar studies. For instance,

Table 6. Chi-Square Test for Differences between Early and Late Responses

\begin{tabular}{|c|c|c|c|c|c|}
\hline Variable & Categories & Early Responses (59) & Late Responses (73) & Chi Square Value & Sig \\
\hline Type of Industry & $\begin{array}{l}\text { Electrical and Electronics } \\
\text { Chemicals } \\
\text { Rubber \& Plastics } \\
\text { Metals \& Machinery }\end{array}$ & $\begin{array}{r}33 \\
7 \\
4 \\
4\end{array}$ & $\begin{array}{l}35 \\
12 \\
10 \\
10\end{array}$ & 8.220 & .314 \\
\hline Age of the Firm & $\begin{array}{l}\geq 15 \text { years } \\
<15 \text { years }\end{array}$ & $\begin{array}{r}7 \\
52\end{array}$ & $\begin{array}{l}25 \\
48\end{array}$ & 8.900 & .285 \\
\hline No. of Employees & $\begin{array}{l}\text { Less than } 100 \\
100-250 \\
251-500 \\
501-1000 \\
\text { More than } 1000\end{array}$ & $\begin{array}{r}6 \\
13 \\
17 \\
7 \\
7 \\
16\end{array}$ & $\begin{array}{r}4 \\
18 \\
20 \\
10 \\
21\end{array}$ & 1.183 & .881 \\
\hline Type of Products & $\begin{array}{l}\text { Consumer products } \\
\text { Industrial Products }\end{array}$ & $\begin{array}{l}27 \\
32\end{array}$ & $\begin{array}{l}29 \\
44\end{array}$ & .487 & .485 \\
\hline Ownership Status & $\begin{array}{l}\text { Malaysian fully owned } \\
\text { Joint venture } \\
\text { American-based } \\
\text { Japanese-based } \\
\text { European-based }\end{array}$ & $\begin{array}{r}18 \\
6 \\
3 \\
26 \\
5\end{array}$ & $\begin{array}{r}21 \\
12 \\
13 \\
20 \\
5\end{array}$ & 8.204 & .145 \\
\hline Green Participation & $\begin{array}{l}\text { Yes } \\
\text { No }\end{array}$ & $\begin{array}{l}34 \\
25\end{array}$ & $\begin{array}{l}38 \\
35\end{array}$ & .409 & .523 \\
\hline Job Title & $\begin{array}{l}\text { Manager } \\
\text { Assistant Manager } \\
\text { Supervisor } \\
\text { Officer } \\
\text { Engineer }\end{array}$ & $\begin{array}{r}24 \\
6 \\
10 \\
11 \\
6\end{array}$ & $\begin{array}{r}38 \\
10 \\
8 \\
8 \\
6\end{array}$ & 3.564 & .468 \\
\hline $\begin{array}{l}\text { Department } \\
\text { attached to }\end{array}$ & $\begin{array}{l}\text { R \& D } \\
\text { Quality control } \\
\text { Operations } \\
\text { EHS } \\
\text { Administrative }\end{array}$ & $\begin{array}{r}0 \\
12 \\
14 \\
20 \\
11\end{array}$ & $\begin{array}{r}5 \\
13 \\
17 \\
25 \\
10\end{array}$ & 4.652 & .325 \\
\hline Years in the firm & $\begin{array}{l}1-5 \\
6-10 \\
11-15 \\
\text { More than } 15 \text { years }\end{array}$ & $\begin{array}{l}14 \\
17 \\
11 \\
15\end{array}$ & $\begin{array}{l}17 \\
22 \\
17 \\
14\end{array}$ & 1.834 & .766 \\
\hline $\begin{array}{l}\text { Qualification } \\
\text { of respondent }\end{array}$ & $\begin{array}{l}\text { Secondary/SPM } \\
\text { Pre U./STPM/Diploma } \\
\text { University degree } \\
\text { Postgraduate degree }\end{array}$ & $\begin{array}{r}2 \\
18 \\
39 \\
8\end{array}$ & $\begin{array}{r}1 \\
10 \\
45 \\
6\end{array}$ & 3.334 & .125 \\
\hline $\begin{array}{l}\text { Gender of } \\
\text { respondent }\end{array}$ & $\begin{array}{l}\text { Male } \\
\text { Female }\end{array}$ & $\begin{array}{l}40 \\
17\end{array}$ & $\begin{array}{l}54 \\
16\end{array}$ & .793 & .373 \\
\hline Age of respondent & $\begin{array}{l}20-30 \\
31-40 \\
41-50 \\
\text { More than } 50 \text { years }\end{array}$ & $\begin{array}{r}14 \\
20 \\
20 \\
3\end{array}$ & $\begin{array}{r}8 \\
27 \\
27 \\
8\end{array}$ & 4.713 & .194 \\
\hline
\end{tabular}


Vachon and Klassen (2006) study on green supply chain initiatives reported a response rate of $23 \%$; Rao (2002) study on green supply chain initiatives in Southeast Asia (including Malaysia) reported a response rate of $10 \%$.

To ensure that the received responses are representative of the population of the study, a response bias is conducted following the procedure suggested by Armstrong and Terry (1977) of comparing early with late responses. Early responses are defined in this study as responses received before sending the first reminder (17 days from the first mailing), whereas late responses are those received after that. According to this criterion, 59 responses are considered early responses and 73 responses are considered late responses. Chi-square test is used to test for significant differences between early and late responses among twelve characteristics of firms and respondents under study. Table 6 presents the results of the test. It is clear from the table that there are no significant differences between early and late responses. All the twelve characteristics of firms and respondents (type of industry, age of the firm, number of employees, type of products, ownership status of the firm, participation in green-interested associations, job title, department attached to, years of work in the firm, qualification, gender, and age of respondents) show no significant differences between early and late responses. Therefore, it can be concluded that non-response bias does not exist in this study.

\subsection{Profile of Sample Firms and Respondents}

The characteristics of responding firms are presented in Table 7 . The table shows that about half $(51.5 \%)$ of the firms belong to the electrical and electronics (E\&E) industry. This is expected because E\&E is the largest industry in Malaysia. The other half distributed between the chemicals, rubber and plastics, and metal and machinery industries. The table shows also that the newly established firms are few in the sample and most of the firms (75.8\%) are old-aged (more than 15 years). Similarly, most firms are considered large firms (more than 250 employees) (about 70\%). This is consistent with the ownership status of the firm which shows that MNCs account for about $70 \%$ of firms while Malaysian fully owned account for $30 \%$ of firms. Regarding type of product, the data shows that more than half $(57.6 \%)$ of the firms are producing industrial products while the rest produces consumer products. This indicates that most firms are suppliers to other firms rather than OEM. The data shows also that most firms $(75.8 \%)$ have more than 10 suppliers which indicate the large supplier base of these firms. Regarding average relationship length with major suppliers and customers, the table reveals that more than $90 \%$ of firms keep long term relationships (more than 5 years) with their suppliers and customers. This gives additional evidence of the existence of relationship orientation in the Malaysian industry. With regard to the souring of material inputs, the table shows that about half of the firms (49.2\%) obtain their input from global sources, and the rest obtain them from domestic and regional sources. This can be linked to the multinational ownership of the firms with no restrictions to the local levels. Finally, more than half of the firms (54.5\%) participate in industry,

Table 7. Profile of Sample Firms

\begin{tabular}{|l|l|c|c|}
\hline \multicolumn{1}{|c|}{ Variables } & \multicolumn{1}{|c|}{ Categories } & Frequency & $\%$ \\
\hline Type of Industry & Electrical and Electronics & 68 & 51.5 \\
& Chemicals & 19 & 14.4 \\
& Rubber \& Plastics & 14 & 10.6 \\
& Metals \& Machinery & 24 & 18.2 \\
No. of Employees & Less than 100 & 10 & 7.6 \\
& $100-250$ & 31 & 23.5 \\
& $251-500$ & 37 & 28.0 \\
& 501-1000 & 17 & 12.9 \\
Type of Products & More than 1000 & 37 & 28.0 \\
Number of & Consumer products & 56 & 42.4 \\
Suppliers & Industrial Products & 76 & 57.6 \\
Supplier Relationship & d" 10 suppliers & 32 & 24.2 \\
Length & More than 10 suppliers & 100 & 75.8 \\
Customer Relationship & 1-5 years & 10 & 7.6 \\
Length & More than 5 years & 122 & 92.4 \\
Source of Inputs & 1-5 years & 4 & 3.0 \\
& More than 5 years & 128 & 97.0 \\
& Domestic & 37 & 28.0 \\
Ownership Status & Regional/Asian & 30 & 22.7 \\
of the Firm & Global & 65 & 49.2 \\
& Malaysian fully owned & 39 & 29.5 \\
Green Associations & Local and Foreign joint venture & 18 & 13.6 \\
Participation & American-based company & 16 & 12.1 \\
& Japanese-based company & 46 & 34.8 \\
& European-based company & 10 & 7.6 \\
& Other (Korean/Taiwanese) & 3 & 2.3 \\
& Yes & 72 & 54.5 \\
& No & 45.5 \\
\hline
\end{tabular}


trade or professional associations that have interest in green issues.

Table 8 shows the profile of respondents (EMRs) who answered the questionnaire. The table reveals that near half $(48.8 \%)$ of the EMRs hold a position of manager (department manager) in their firms, while the rest are assistant managers (12.6\%), supervisors $(14.2 \%)$, officers $(15 \%)$, and engineers $(9.4 \%)$. The highest proportion of EMRs are attached to the environment, health and safety department in their firms $(35.4 \%)$ followed by operations or production department $(24.4 \%)$, quality control department $(19.7 \%)$, administrative (HRM or general administration) department $16.5 \%$ ), and research and development ( $R$ \& D) (3.9\%). Regarding the experience of EMRs in their firms, the data reveals that about $75 \%$ have more than five years of work in their firm, which indicates that the EMRs were selected from the most experienced persons in their firms. Similarly, the table shows that $73.9 \%$ of the EMRs hold university or postgraduate degrees. The data shows also that $74 \%$ of the EMRs are male and $26 \%$ are female. Lastly, the table reveals that most respondents are in the middle range age (30-50

Table 8.Profile of Respondents

\begin{tabular}{|l|l|c|c|}
\hline \multicolumn{1}{|c|}{ Variables } & \multicolumn{1}{|c|}{ Categories } & Frequency & $\%$ \\
\hline Job Title & Manager & 62 & 48.8 \\
& Assistant Manager & 16 & 12.6 \\
& Supervisor & 18 & 14.2 \\
& Officer & 19 & 15.0 \\
Engineer & 12 & 9.4 \\
attached to & R \& D & 5 & 3.9 \\
& Quality control & 25 & 19.7 \\
& Operations/Production & 31 & 24.4 \\
Number of years & Environment, Health \& safety & 45 & 35.4 \\
in the firm & Administrative & 21 & 16.5 \\
& $1-5$ & 31 & 24.4 \\
& 6-10 & 39 & 30.7 \\
Qualification & $11-15$ & 28 & 22.0 \\
of respondent & More than 15 years & 29 & 22.8 \\
& Secondary/SPM & 3 & 2.3 \\
& Pre U./STPM/Diploma & 28 & 21.2 \\
Gender of respondent & University degree & 84 & 63.3 \\
& Postgraduate degree & 14 & 10.6 \\
& Male & 94 & 74.0 \\
Age of respondent & Female & 33 & 26.0 \\
& 20-30 & 22 & 17.3 \\
& 31-40 & 47 & 37.0 \\
& $41-50$ & 47 & 37.0 \\
& More than 50 years & 11 & 8.7 \\
\hline
\end{tabular}

years) (74\%) while the rest are between $20-30$ years $(17.3 \%)$ and above 50 years $(8.7 \%)$.

\subsection{Goodness of Measures}

Goodness of measures was gauged in this study using validity and reliability tests. Exploratory factor analysis is used for testing the validity of measures of all the variables under study. The reliability or internal consistency of measures was tested using Cronbach's alpha test. The following subsections illustrate the results of factor and reliability tests. Factor analysis was performed for all the items included in green supply chain initiatives. The analysis starts with evaluating the appropriateness of the data or correlation matrix for factor analysis. The KMO measure should be at least 0.6 and Bartlett's test of spherecity should be significant $(\mathrm{p}<.05)$ (Hair et al., 1998; Pallant, 2003). By inspecting the values in Table 9, the KMO measure of sampling adequacy is 0.88 and the Bartlett's test of spherecity is significant $(\mathrm{p}<.01)$ which indicates that the matrix meets the assumption of factor analysis and can be factorized.

Table 9 indicates that green supply chain initiatives items load into three factors with eigenvalues exceeding 1 . The three extracted factors matched the three conceptualized types of green supply chain initiatives; green purchasing, ecodesign, and reverse logistics. All items for green purchasing loaded in factor 1 with loading values above the specified limit of 0.45 and cross loadings below 0.35. Similarly, the items of eco-design and reverse logistics loaded on factors 2 and 3 , respectively, with loading values above 0.45 and cross loadings below 0.35 . The total variance explained by the three factors is $67.47 \%$ which exceeded the minimum value of 0.60 recommended by Hair et al. (1998).

\subsection{Reliability Analysis}

Reliability analysis is conducted in this study to ensure that the measures of variables have internal consistency across time and across the various items that measure the same concept or variable (Sekaran, 2003). Reliability is measured in this study using Cronbach's alpha coefficients. The measures are considered to have sufficient level of reliability when Cronbach's alpha values equal to or greater than 0.70 (Nunally, 1987). Table 10 provides the values of Cronbach's alpha for the variables. It appears from 
Table 9. Rotated Factor Loadings for Green Supply Chain Initiatives

\begin{tabular}{|c|c|c|c|c|}
\hline \multirow{2}{*}{$\begin{array}{l}\text { Item } \\
\text { No. }\end{array}$} & \multirow{2}{*}{ Items: Currently my firmÖ.. } & \multicolumn{3}{|c|}{ Component } \\
\hline & & 1 & 2 & 3 \\
\hline GP1 & Provides green design specifications to suppliers & .705 & .314 & -.006 \\
\hline GP2 & Requires suppliers to develop and maintain EMS & .756 & 135 & .184 \\
\hline GP3 & Requires suppliers to have a certified EMS & .758 & .124 & .248 \\
\hline GP4 & Uses questionnaires to collect information about suppliers & .785 & .124 & .076 \\
\hline GP5 & Makes sure that its purchased products must contain green attributes & .675 & .315 & .148 \\
\hline GP6 & $\begin{array}{l}\text { Makes sure that its purchased products must not contain environmentally } \\
\text { undesirable items }\end{array}$ & .794 & .229 & -.023 \\
\hline GP7 & Evaluates its suppliers based on specific environmental criteria & .866 & .213 & .001 \\
\hline GP8 & Evaluates environmental aspects of its second-tier suppliers & .820 & .044 & .279 \\
\hline GP9 & Makes sure that its suppliers meet environmental objectives. & .754 & .173 & .139 \\
\hline ED1 & Produces products that have reused or recycled materials in their contents. & .178 & .729 & .246 \\
\hline ED2 & Uses life cycle assessment to evaluate the environmental load of its products. & .325 & .582 & .211 \\
\hline ED3 & Produces products that are free from hazardous substances. & .237 & 698 & -.040 \\
\hline ED4 & Makes sure that its products have recyclable or reusable contents. & .195 & .808 & .21. \\
\hline ED5 & $\begin{array}{l}\text { Produces products that reduce the consumption of materials or energy } \\
\text { during use. }\end{array}$ & .095 & .818 & .208 \\
\hline ED6 & Makes sure that its packaging has recyclable contents. & .292 & .797 & .233 \\
\hline ED7 & Makes sure that its packaging is reusable. & .325 & .763 & .29 \\
\hline ED8 & Minimizes the use of materials in its packaging. & .087 & .725 & .258 \\
\hline ED9 & Avoids or reduces use of hazardous materials in its packaging. & .129 & .695 & .144 \\
\hline RL1 & $\begin{array}{l}\text { Collects back used products from customers for recycling, reclamation } \\
\text { of materials, or reuse. }\end{array}$ & .033 & .190 & .767 \\
\hline RL2 & Collects back used packaging from customers for reuse or recycling. & 173 & .244 & .738 \\
\hline RL3 & Requires suppliers to collect back their packaging materials. & .193 & .212 & .793 \\
\hline RL4 & $\begin{array}{l}\text { Returns back its products to suppliers for recycling, retaining of materials, } \\
\text { or remanufacturing. }\end{array}$ & .004 & .246 & .854 \\
\hline RL5 & Returns back its packaging to suppliers for reuse or recycling. & .090 & .153 & .833 \\
\hline \multirow[t]{6}{*}{ RL6 } & Returns back the products from customers for safe refill. & .264 & .189 & .793 \\
\hline & Eigenvalues & 10.361 & 3.493 & 2.338 \\
\hline & Percentage of Variance Explained & 43.171 & 14.555 & 9.740 \\
\hline & Total Variance Explained (\%) & \multicolumn{3}{|c|}{67.466} \\
\hline & Kaiser-Meyer-Olkin (KMO) & \multicolumn{3}{|c|}{.888} \\
\hline & Bartlett's Test of Spherecity & \multicolumn{3}{|c|}{$2650.655^{\star *}$} \\
\hline
\end{tabular}

Note: Extraction Method: Principal Component Analysis. Rotation Method: Varimax with Kaiser Normalization. $n=132 .{ }^{* *} p<$ 0.01

the table that the values of Cronbach's alpha ranges between 0.914 and 0.931 . These values well exceed the minimum value of 0.70 . Thus, it can be concluded that the measures have acceptable level of reliability.

Table 10. Cronbach's Alpha for Study Variables

\begin{tabular}{|l|c|c|c|}
\hline \multicolumn{1}{|c|}{ Variable } & $\begin{array}{c}\text { Number of } \\
\text { Item }\end{array}$ & $\begin{array}{c}\text { Number of } \\
\text { Deleted Item }\end{array}$ & $\begin{array}{c}\text { Cronbach } \\
\text { Alpha }\end{array}$ \\
\hline Green purchasing & 9 & - & 0.929 \\
Eco-design & 9 & - & 0.931 \\
Reverse logistics & 6 & - & 0.914 \\
\hline
\end{tabular}

\subsection{Descriptive Analysis of Green Supply Chain Initiatives}

Table 11 provides means and standard deviations of the three types of green supply chain initiatives under study; green purchasing, eco-design, and reverse logistics. Taking into consideration that the scale used for green supply chain initiatives adoptions is 1 to 5 (with 3 is the middle point), the table shows that the most adopted green supply chain initiative in the Malaysian industry is ecodesign (mean=3.48, standard deviation=0.79), followed by green purchasing (mean $=3.37$, standard deviation=0.74), and the lowest adopted green supply chain initiative is reverse logistics (mean $=2.74$, standard deviation $=0.87$ ). This means 
that, on average, the Malaysian firms adopted high level of eco-design and green purchasing, and low reverse logistics.

Table 11. Descriptive Statistics of Green Supply Chain Initiatives

\begin{tabular}{|l|c|c|}
\hline \multicolumn{1}{|c|}{ Variable } & Mean & $\begin{array}{c}\text { Standard } \\
\text { Deviation }\end{array}$ \\
\hline Green Purchasing & 3.37 & .74 \\
Eco-Design & 3.48 & .79 \\
Reverse Logistics & 2.74 & .87 \\
\hline
\end{tabular}

Note: All variables used a 5 -point Likert scale with $(1=$ not at all adopted, $5=$ very high extent of adoption)

To see how green supply chain initiatives differ between dichotomous characteristics of the firms, $t$ tests were conducted on green supply chain initiatives by age of the firm (new and old firms), type of product (consumer and industrial product), number of suppliers (small and large), and participation in green-interested associations (yes and no). Table 12 discloses that there are no significant differences in green supply chain initiatives between new and old firms, and between consumer and industrial products. However, there are significant differences in green purchasing and eco-design between small and large supplier base. The mean values indicate that green purchasing and eco-design are adopted by firms that have large number of suppliers compared with firms that have small number of suppliers. The table shows also that there are significant differences in all the three types of green supply chain initiatives between firms that participate in industry, trade or professional associations that have interest in green issues and firms that do not.
Close inspection of the means reveals that firms that participate in such associations adopt more green supply chain initiatives than firms that do not. The respondents were asked to specify which associations their firms participated in. The respondents mentioned variety of associations such as Sony Green Partner, Canon Green Product, Pioneer Green Partner, Ecoleaf, RoHS, JVC, Mitsubishi, Jackim, FMM, MICCI, and SIRIM. It is clear that most of these associations are developed by large firms.

One-way ANOVA tests were used to test green supply chain initiatives differences among attributes of firms that include more than two values. These attributes include type of industry, number of employees (firm size), source of inputs, and type of ownership. Table 13 presents summary of the tests. The table shows significant differences in green purchasing among the four types of industry. The mean values indicate that electrical and electronics (E \& E) have the highest level of green purchasing initiative followed by metals and machinery, chemicals, and rubber and plastics. The table shows no significant differences in eco-design and reverse logistics among the four types of industry. Regarding the number of employees, the table discloses significant differences in green purchasing and ecodesign among sizes of firms. Close inspection of the means indicate that green purchasing and eco-design increase as the number of employees (firm size) increase. For reverse logistics, although the mean values show general increase in reverse logistics as the firm size increases, the differences are not significant. These results generally indicate that green supply chain initiatives are adopted more by large firms than by smaller ones.

Table 12. T-tests for of Green Supply Chain Initiatives Differences

\begin{tabular}{|c|c|c|c|c|c|c|c|c|c|c|}
\hline \multirow{2}{*}{\multicolumn{2}{|c|}{ Firm Attributes }} & \multicolumn{3}{|c|}{ Green Purchasing } & \multicolumn{3}{|c|}{ Eco Design } & \multicolumn{3}{|c|}{ Reverse Logistics } \\
\hline & & Mean & SD & $t$-value & Mean & SD & $\mathrm{t}$-value & Mean & SD & $\mathrm{t}$-value \\
\hline Firm age & $\begin{array}{l}<15 \text { years } \\
>15 \text { years }\end{array}$ & $\begin{array}{l}3.18 \\
3.42\end{array}$ & $\begin{array}{l}.877 \\
.710\end{array}$ & -1.609 & $\begin{array}{l}3.47 \\
3.47\end{array}$ & $\begin{array}{l}.905 \\
.789\end{array}$ & .027 & $\begin{array}{l}2.57 \\
2.79\end{array}$ & $\begin{array}{l}.866 \\
.890\end{array}$ & -1.228 \\
\hline Type of product & $\begin{array}{l}\text { Consumer } \\
\text { Industrial }\end{array}$ & $\begin{array}{l}3.46 \\
3.30\end{array}$ & $\begin{array}{l}.779 \\
.740\end{array}$ & 1.208 & $\begin{array}{l}3.57 \\
3.39\end{array}$ & $\begin{array}{l}.719 \\
.876\end{array}$ & 1.220 & $\begin{array}{l}2.77 \\
2.71\end{array}$ & $\begin{array}{l}.864 \\
.907\end{array}$ & .399 \\
\hline Number of supplier & $\begin{array}{l}<10 \text { suppliers } \\
>10 \text { suppliers }\end{array}$ & $\begin{array}{l}3.09 \\
3.45\end{array}$ & $\begin{array}{l}.710 \\
.755\end{array}$ & $-2.386^{*}$ & $\begin{array}{l}3.18 \\
3.56\end{array}$ & $\begin{array}{l}.666 \\
.840\end{array}$ & $-2.309^{*}$ & $\begin{array}{l}2.70 \\
2.75\end{array}$ & $\begin{array}{l}.689 \\
.944\end{array}$ & -.272 \\
\hline $\begin{array}{l}\text { Green Association } \\
\text { Participation }\end{array}$ & $\begin{array}{l}\text { Yes } \\
\text { No }\end{array}$ & $\begin{array}{l}3.50 \\
3.21\end{array}$ & $\begin{array}{l}.695 \\
.805\end{array}$ & $-2.220^{*}$ & $\begin{array}{l}3.73 \\
3.16\end{array}$ & $\begin{array}{l}.719 \\
.820\end{array}$ & $-4.23^{\star \star}$ & $\begin{array}{l}2.92 \\
2.52\end{array}$ & $\begin{array}{l}.849 \\
.887\end{array}$ & $-2.64^{\star \star}$ \\
\hline
\end{tabular}

Note: ${ }^{*} p<0.05,{ }^{* *} p<0.01, S D=S t a n d a r d$ Deviation 
Table 3. ANOVA tests for Differences of Green Supply Chain Initiatives by Some Elements of Firms' Profile

\begin{tabular}{|c|c|c|c|c|c|c|c|c|c|c|}
\hline \multirow{2}{*}{\multicolumn{2}{|c|}{ Firm Attributes }} & \multicolumn{3}{|c|}{ Green Purchasing } & \multicolumn{3}{|c|}{ Eco Design } & \multicolumn{3}{|c|}{ Reverse Logistics } \\
\hline & & Mean & SD & $\mathrm{t}$-value & Mean & SD & t-value & Mean & SD & $t$-value \\
\hline \multirow{4}{*}{ Type of Industry } & $E \& E$ & 3.64 & .697 & \multirow{4}{*}{$10.2^{\star \star}$} & 3.49 & .835 & & 2.73 & .964 & \multirow{4}{*}{.753} \\
\hline & Chemicals & 3.06 & 632 & & 3.15 & 907 & \multirow{3}{*}{1.874} & 2.51 & 1.046 & \\
\hline & Rubber \& Plastics & 2.69 & .612 & & 3.32 & .571 & & 2.79 & .791 & \\
\hline & Metals \& Machinery & 3.31 & .597 & & 3.69 & .661 & & 2.92 & .541 & \\
\hline \multirow{5}{*}{$\begin{array}{c}\text { Number of employees } \\
\text { (Firm size) }\end{array}$} & $<100$ & 3.06 & .721 & \multirow{5}{*}{$3.435^{\star}$} & 2.73 & .921 & \multirow[t]{5}{*}{$3.192^{*}$} & 2.08 & .672 & \multirow{5}{*}{1.989} \\
\hline & $100-250$ & 3.15 & .814 & & 3.55 & .800 & & 2.68 & .691 & \\
\hline & $251-500$ & 3.28 & .786 & & 3.35 & .903 & & 2.82 & .925 & \\
\hline & $501-1000$ & 3.34 & .566 & & 3.55 & .605 & & 2.64 & .844 & \\
\hline & $>1000$ & 3.72 & .668 & & 3.68 & .687 & & 2.92 & 1.003 & \\
\hline \multirow{3}{*}{ Sources of Inputs } & Domestic & 3.31 & .825 & \multirow{3}{*}{.923} & 3.40 & 1.034 & \multirow[t]{3}{*}{.801} & 2.56 & .932 & \multirow{3}{*}{1.725} \\
\hline & Regional/Asian & 3.24 & .604 & & 3.36 & .696 & & 2.64 & .841 & \\
\hline & Global & 3.45 & .782 & & 3.56 & .722 & & 2.88 & .870 & \\
\hline \multirow{5}{*}{ Type of Ownership } & Malaysian & 3.01 & .615 & \multirow{5}{*}{$6.17^{\star \star}$} & 3.08 & .747 & \multirow[t]{5}{*}{$5.00^{\star \star}$} & 2.47 & .809 & \multirow{5}{*}{$2.874^{\star}$} \\
\hline & Joint venture & 3.15 & .794 & & 3.41 & .605 & & 2.77 & .852 & \\
\hline & American & 3.19 & 1.051 & & 3.64 & 1.079 & & 2.46 & .948 & \\
\hline & Japanese & 3.70 & .567 & & 3.56 & .777 & & 3.01 & .887 & \\
\hline & European & 3.63 & .661 & & 4.19 & .438 & & 3.02 & .743 & \\
\hline
\end{tabular}

Note: ${ }^{*} \mathrm{p}<0.05,{ }^{* *} \mathrm{p}<0.01, \mathrm{SD}=$ Standard Deviation

For the sources of inputs, the table shows no significant differences in green supply chain initiatives for firms that source their material inputs from domestic, regional, or global sources. However, significant differences are noticeable in all the three types of green supply chain initiatives among types of company ownership. The mean values show that green purchasing is highest in Japanese and European based firms, followed by American-based and joint venture firms, and lastly Malaysian fully owned firms. For eco-design, European-based showed the highest mean values followed by American, Japanese, joint venture, and finally Malaysian fully owned firms. Similar mean values were reported for reverse logistics. These results generally indicate that Malaysian fully owned firms have lower green supply chain initiatives compared with foreign firms (MNCs' subsidiaries).

\section{Discussions}

The major findings of the study is eco-design is the most highly adopted green supply chain initiative among the certified manufacturing firms in Malaysia, followed by green purchasing. The least adopted green supply chain imitative is reverse logistics. The results of the study showed that the Malaysian firms, on average, adopt above average eco-design (mean=3.48), above average green purchasing (mean=3.37), and low reverse logistics (mean=2.78). These results generally indicate green supply chain initiatives are not highly adopted in Malaysia despite the importance of green supply chain initiatives to a firm and society. The results also indicate that green supply chain initiatives that involve external relationships with suppliers and customers (green purchasing and reverse logistics) have lower level of adoption compared with the internally-focused green supply chain initiatives (eco-design) that involves less external relationships. The result also showed there is a low level of reverse logistics in the Malaysian firms. This can be due to the high costs and other constraints involved in reverse logistics (Geyer \& Jackson, 2004).

One possible explanation for the low level of green supply chain initiatives is the high cost of adopting green supply chain initiatives coupled with less visible economic benefits from these initiatives (Anbumozhi \& Kanda, 2005; Min \& Galle, 2001). In the interview with SIRIM representative, he mentioned that green products are expensive compared to non-green products and there is little demand on them. He claimed that high cost of green 
initiatives is due to the reason that they have to buy more environmental or eco-design materials. Another explanation is the lack of capabilities to adopt green supply chain initiatives. Complexity of green supply chains represents challenge to many firms. Guide et al. (2003) argued that product returns are uncertain in quality, quantity, and timing compared with new products. Therefore, it is easy for firms to manage forward supply chains than the reverse one. Abdullah (1995, p.197) mentioned that "many Malaysian industries are still unable or perhaps unwilling to comply with the standards of discharges and emissions due to the lack of capabilities such as non-availability of cost-effective technologies".

Comparison of green supply chain initiatives among different characteristics of firms revealed that the level of green purchasing and eco-design adoptions are higher in larger firms than in smaller firms. This is evidenced by significant increase in green purchasing and eco-design as number of employee's increases. The result was evidenced also by the result that firms with large number of suppliers adopt more green purchasing and ecodesign than firms with lower number of suppliers. Large number of suppliers indicates that a firm is large is size. This result implies that large firms adopt more green supply chain initiatives than smaller firms. Large firms are generally had more resources and capabilities than smaller firms which enable them to attempt costly and/or risky environmental investments (Bowen, 2002). Larger firms are also more visible in society that induces them to adhere to environmental standards so as not to lose stakeholder support (Bowen, 2002). Anbumozhi and Kanda (2005) found that only big businesses have committed to voluntarily environmental initiatives in Asia and this approach is yet to be accepted by SMEs. Similarly, the representative from SIRIM mentioned that: "other than MNCs, local companies have lower level of awareness of environmental practices and don't have own initiatives".

Closely linked to firm size is ownership type of the firm. The results showed that green supply chain initiatives differ between types of ownership. Malaysian fully owned firms have the lowest level of green supply chain initiatives compared with foreign-based firms. Similar to firm size, this difference can be attributed to the large amount of resources and capabilities available to foreignbased firms. Within foreign firms, the study found that Japanese and European based firms have higher level of green supply chain initiatives compared with American-based firms. Previous studies also found that US businesses differ from their European counterparts in terms of green activism and awareness (Murphy \& Poist, 2003). Carter et al. (1998) found also that German purchasing managers are much more involved than their US counterparts with respect to environmental purchasing. The study found that firms that participate in green associations adopted higher green supply chain initiatives than firms that do not participate. A closer look at these associations reveals that most of them belong to big firms such as Sony group, Cannon, JVC, and Mitsubishi. From these associations firms learn principles and standards of green initiatives as well as benefits and value of such initiatives. This increases the level of awareness of green issues among organizations and, subsequently, level of adoption. DiMaggio and Powell (1983) mentioned professional and trade associations as important vehicle for the definition and promulgation of normative rules about organizational and professional behavior.

\subsection{Implications for Research}

Based on the above analysis, it is clear that researchers need conduct studies that help in clarifying the concepts of environmental management and sustainable development, developing viable solutions to barriers to green efforts, and disclosing benefits of environmental endeavors. Specifically, future studies are needed in the following areas:

1. Specifying the requirements of environmental actions in relation to peculiar conditions and situations in Malaysia.

2. Outlining the roles of government agencies, community organizations, NGOs, and other institutions in leveraging environmental initiatives in Malaysia.

3. Suggesting solutions for the difficulties and problems facing business organizations in adopting environmental initiatives. 


\subsection{Implications for Managers}

Managers in private and public institutions can take numerous actions to improve and support movement towards environmentally conscious society as follows:

1. Raising awareness of importance and role of EM: Many firms have no awareness of the necessity to adopt EM. Only some firms whose main markets are abroad or companies that produce parts and materials to be supplied to the manufacturers of products for export have the tendency to practice EM (GPNM, 2003). Therefore, efforts are needed to raise the level of EM awareness among firms in Malaysia.

2. Education and Training for Environmental Management: Involves designing educational programs for sustainability. Education programs involve; product design, waste management, and pollution control. Such programs can help in raising skills and capabilities related to the implementation of environmental initiatives

3. Designing of appropriate regulations: There is a general lack of appropriate regulations by government as well as business organizations. Most regulations encourage waste minimization but not higher levels of EM such as DFE and green supply chains. There are various regulations adopted by other countries that extend the responsibility of manufacturers to include not only waste created during manufacturing stage but also waste caused by the product after waste. Examples of these regulations include packaging waste order in Germany, the packaging covenant in the Netherlands, Waste of Electrical and Electronic Equipment directive (WEEE) in European Union, and voluntary agreement on the cost bearing of waste automobile treatment among German automakers (Hassan et al., 2006; Lee, 2000).

\subsection{Conclusion}

Environmental issues become a major concern for business as well as public organizations. Therefore, efficient policies need to be designed to alleviate these issues. However, proper design of these policies require proper understanding of the steps needed towards sustainability as well as barriers and obstacles facing greening activities. Much research and efforts need to be done to support the evolution of business activities towards sustainable development. This paper is an attempt to clarify the path towards that end and highlight steps to be taken by business organizations to make sustainable development a reality.

\section{References}

Abdullah, A.R. (1995). Environmental pollution in Malaysia: trends and prospects. Trends in Analytical Chemistry, 14(5), pp. 191-198.

Alvarez-Gil, M.J., Berrone, P., Husillos, F.J. and Lado, N. (2007). Reverse logistics, stakeholders' influence, organizational slack, and managers' posture. Journal of Business Research, 60(5), pp. 463-473.

Anbumozhi, V. and Kanada, Y. (2005). Greening the production and supply chains in Asia: is there a role for voluntarily initiatives? IGES Kansai Research Center Discussion Paper, KRC-2005, No. 6E. Available online: http://www.iges.or.jp

APO (Asian Productivity Organization) (2004). Eco-Products Directory 2004. Asian Productivity Organization, Tokyo.

Banerjee, S.B. (2001). Corporate environmental strategies and actions. Management Decision, 39(1), pp. 36-44.

Bansal, P. \& Roth, K. (2000). Why companies go green: a model of ecological responsiveness. Academy of Management Journal, 43(4), pp. 717-736.

Blumberg, D.F. (1999). Strategic examination of reverse logistics \& repair service requirements, needs, market size, and opportunities. Journal of Business Logistics, 20(2), pp. 141-159.

Bowen, F.E., Cousins, P.D., Lamming, R.C. and Faruk, A.C. (2001a). The role of supply management capabilities in green supply. Production and Operations Management, 10(2), pp. 174-189.

Bowen, F.E., Cousins, P.D., Lamming, R.C. and Faruk, A.C. (2001b). Horses for courses: explaining the gap between the theory and practice of green supply. Greener Management International, 35, pp. 41-60.

Canning, L. and Hanmer-Lloyd, S. (2001). Managing the environmental adaptation process in supplier-customer relationships. Business Strategy and the Environment, 10, pp. 225-237.

Carter, C.R. and Carter, J.R. (1998). Interorganizational determinants of environmental purchasing: initial evidence from the consumer products industries. Decision Sciences, 29(3), pp. 659-684. 
Carter, C.R. and Ellram, L.M. (1998). Reverse logistics: a review of the literature and framework for future investigation. Journal of Business Logistics, 19(1), pp. 85-102.

Curkovic, S., Sroufe, R. \& Melnyk, S. (2005). Identifying the factors which affect the decision to attain ISO 14000. Energy, 30(8), pp. 1387-1407.

Darnall, N., Jolley, G.J. and Handfield, R. (2006). Environmental management systems and green supply chain management: complements for sustainability? Business Strategy and the Environment, article in press, DOI: 10.1002/bse.557.

Darnall, N., Jolley, G.J. and Handfield, R. (2006). Environmental management systems and green supply chain management: complements for sustainability? Business Strategy and the Environment, article in press, DOI: 10.1002/bse.557.

DiMaggio, P.L. \& Powell, W.W. (1983). The iron cage revisited: institutional isomorphism and collective rationality in organizational fields. American Sociological Review, 48, pp. 147-160.

Geyer, R. \& Jackson, T. (2004). Supply loops and their constraints: the industrial ecology of recycling and reuse. California Management Review, 46(2), pp. 55-73.

Goldsby, T.J. \& Stank, T.P. (2000). World class logistics performance and environmentally responsible logistics practices. Journal of Business Logistics, 21(2), pp. 187-208.

Guide, V.D.R., Harrison, T.P. \& van Wassenhove, L.N. (2003). The challenge of closed-loop supply chains. Interfaces, 33(6), pp. 3-6.

Hair, J.F., Anderson, R.E., Tatham, R.L. \& Black, W.C. (1998). Multivariate Data Analysis (5 ${ }^{\text {th }}$ ed.). Prentice Hall Inc., Upper Saddle River, NJ.

Hall, J. (2000). Environmental supply chain dynamics. Journal of Cleaner Production, 8 (6), pp. 455-471.

Hamner, B. (2006). Effects of green purchasing strategies on supplier behavior. In Sarkis, Chapter 2, pp. 25-37.

Handfield, R.B., Sroufe, R. \& Walton, S.V. (2005). Integrating environmental management and supply chain strategies. Business Strategy and the Environment, 14(1), pp. 1-19.

Handfield, R.B., Walton, S.V., Seegers, L.K. and Melnyk, S.A. (1997). 'Green' value chain practices in the furniture industry. Journal of Operations Management, 15(4), pp. 293-315.

Hart, S.L. (1997). Beyond greening: strategies for a sustainable world. Harvard Business Review, 75(1), pp. 66-76.

Hervani, A.A., Helms, M.M. and Sarkis, J. (2005). Performance measurement for green supply chain management. Benchmarking: An International Journal, 12(4), pp. 330-353.

IPCC (2007). Assessing key vulnerabilities and the risk from climate change. Available at: http://www.ipcc-wg2.org.
IPCC (2007). Climate Change 2007: The Physical Science Basis, Summary for Policymakers. Available online: http:// www.ipcc.ch/SPM2feb07.pdf.

Johansson, G. (2002). Success factors for integration of ecodesign in product development: a review of state of the art. Environmental Management and Health, 13(1), pp. 98-107.

Klassen, R.D. \& McLaughlin, C.P. (1996). The impact of environmental management on firm performance. Management Science, 42(8), pp. 1199-1214.

Matos, S. \& Hall, J. (2007). Integrating sustainable development in the supply chain: the case of life cycle assessment in oil and gas and agricultural biotechnology. Journal of Operations Management, article in press, doi:10.1016/j.jom.2007.01.013.

Matthews, D.H. (2003). Environmental management systems for internal corporate environmental benchmarking. Benchmarking: An International Journal, 10(2), pp. 95-106.

MIDA (Malaysian Industrial Development Authority) (2007). Performance of the manufacturing and related services sectors 2005. Available at: http:// www.mida.gov.my.

Min, H. \& Galle, W.P. (2001). Green purchasing practices of US firms. International Journal of Production and Operations Management, 21(9), pp. 1222-1238.

Mollenkopf, D.A. \& Closs, D.J. (2005). The hidden value in reverse logistics. Supply Chain Management Review, 9(5), 3 pp. 4-43.

Murphy, P.R. and Poist, R.F. (2003). Green perspectives and practices: a "comparative logistics" study. Supply Chain Management: An International Journal, 8(2), pp. 122-131.

Murphy, P.R. and Poist, R.F. (2003). Green perspectives and practices: a "comparative logistics" study. Supply Chain Management: An International Journal, 8(2), pp. 122-131.

Netherwood, A. (1996). Environmental management systems. In Welford, R. (ed.). Corporate Environmental Management: Systems and Strategies. Earthscan Publications Ltd., London, chapter 3, pp. 35-58.

Nunnally, J.C. (1978). Psychometric Theory. New York, McGraw Hill.

Porter, M.E. \& van der Linde, C. (1995). Green and competitive: ending the stalemate. Harvard Business Review, 73 (5), pp. 120-134.

Preuss, L. (2001). In dirty chains? Purchasing and greener manufacturing. Journal of Business Ethics, 34(3), pp. 345-359.

Rao, P. (2002). Greening the supply chain: a new initiative in South East Asia. International Journal of Operations and Production Management, 22(6), pp. 632-655.

Rao, P. (2006). Greening of suppliers/in-bound logistics in the South East Asian context. In Sarkis, Chapter 11, pp. 189-204. 
Ravi, V., Shankar, R. and Tiwari, M.K. (2005). Productivity improvement of a computer hardware supply chain. International Journal of Productivity and Performance Management, 54(4), pp. 239-255.

Richey, R.G., Genchev, S.E. \& Daugherty, P.J. (2005). The role of resource commitment and innovation in reverse logistics performance. International Journal of Physical Distribution $\mathcal{E}$ Logistics Management, 35(4), pp. 233-257.

Sarkis, J. (1998). Evaluating environmentally conscious business practices", European Journal of Operational Research, 107(1), pp. 159-174.

Sarkis, J. (ed.) (2006). Greening the Supply Chain. Springer, London

Sekaran, U. (2003). Research Methods for Business: A Skill Building Approach. John Willey \& Sons, Inc., Singapore.

Sinding, K. (2000). Environmental management beyond the boundaries of the firm: definitions and constraints. Business Strategy and the Environment, 9(2), pp. 79-91.

Sroufe, R. (2003). Effects of environmental management systems on environmental management practices and operations. Production and Operations Management, 12(3), pp. 416-431.

Stock, J., Speh, T. \& Shear, H. (2006). Managing product returns for competitive advantage. MIT Sloan Management Review, 48(1), pp. 57-62.

Vachon, S. and Klassen, R.D. (2006a). Extending green practices across the supply chain: the impact of upstream and downstream integration. International Journal of Operations E production Management, 26(7), pp. 795-821.

Vachon, S. and Klassen, R.D. (2006b). Green project partnership in the supply chain: the case of package printing industry. Journal of Cleaner production, 14(6), pp. 661-671.
Walton, S.V., Handfield, R.B. and Melnyk, S.A. (1998). The green supply chain: integrating suppliers into environmental management process. International Journal of Purchasing and Materials Management, 34(2), pp. 2-11.

WBCSD (2006). Eco-efficiency. Available at: http:// www.wbcsd.org/DocRoot/

WBCSD (World Business Council for Sustainable Development) (1996) Sustainable Production and Consumption: A Business Perspective. Conches-Geneva, Switzerland: WBCSD.

WCED (World Commission on Environment and Development) (1987). Our Common Future. The Oxford University Press, New York.

Welford, R. (2000). Corporate Environmental Management: Towards Sustainable Development. Earthscan Publications Ltd., London.

Zhu, Q., Sarkis, J. and Lai, K. (2007). Green supply chain management: pressures, practices and performance within the Chinese automobile industry. Journal of Cleaner Production, 15(11-12), 1041-1052.

Zhu, Q., Sarkis, J., Cordeiro, J.J. \& Lai, K. (2008). Firm-level correlates of emergent green supply chain management practices in the Chinese context. Omega, 36, 577-591.

Zsidisin, G.A. \& Siferd, S.P. (2001). Environmental purchasing: a framework for theory development. European Journal of Purchasing E Supply Management, 7(1), pp. 61-73.

Tarig Khidir Eltayeb is a doctoral student in School of Management, Universiti Sains Malaysia

Dr. Suhaiza Zailani is an Associate Professor of Operations Management in the School of Management, Universiti Sains Malaysia. She has been teaching for the past 10 years as well as being involved in a few management consultancies focusing on the areas of operations management. She has more than 150 Research Publications in International/ National Seminars and Journals. She is quite comfortable in operations project related. Her areas of interest are supply chain, logistics, and transportations by involving in few important projects, which describe her capability. 